\title{
The Molecular Evolution and DNA Profiling of Toxic Cyanobacteria
}

\author{
Brett A. Neilan* \\ School of Biotechnology and Biomolecular Sciences, \\ The University of New South Wales, Sydney 2052, \\ Australia
}

\begin{abstract}
Rapid and sensitive methods for the detection and genetic characterization of cyanobacteria have been developed based on DNA amplification techniques. This article describes the molecular methods that have been used to characterize cyanobacteria and their use as tools to identify toxin-producing strains. Different species and strains were compared using restriction fragment length polymorphism (RFLP) of amplified fragments of the phycocyanin gene and the 16S-23S rRNA internal transcribed spacer.
\end{abstract}

\section{Introduction}

Current protocols for cyanobacterial classification rely on the observation of morphological parameters. Many of the biochemical (e.g. range of carbon substrates for heterotrophic growth) and physiological properties used in prokaryotic systematics are not appropriate markers for the study of cyanobacterial taxonomy. Therefore strain discrimination based on relatively simple and often minor morphological differences has been used to describe this immensely diverse bacterial phylum. Expression of phenotypes in cyanobacteria, as with other organisms, is often affected by environmental conditions. Typical manifestations of this are seen during laboratory selective culturing of cyanobacterial isolates, exemplified by the loss of gas vacuoles and colonial habit in planktonic strains (13 ). Hence classifications of cyanobacteria, and certain other prokaryotes, based solely on morphology has been described as artificial and arbitrary.

For more than 150 years cyanobacteria were considered to be eukaryotic algae prior to the efforts of Gibbons and Murray (4) and Stanier et al. (5). The inclusion of cyanobacteria under the bacteriological code resulted in the collection of strains as pure cultures instead of herbarium samples, as required for botanical systematics. More importantly, this recognition of cyanobacteria as prokaryotes allowed the postulation of cyanobacterial evolution for taxa within the radiation, with regards to other bacteria, and to other photosynthetic organisms (6). The ubiquity and relative conservation of the 16S rRNA gene across life forms makes it an appropriate molecule for inferring phylogeny. Comparisons of 16S rRNA gene sequences has supported the previously described

*For correspondence. Email b.neilan@unsw.edu.au; Fax. 612-93856528 affiliations between cyanobacteria and related organisms. Specifically, members of the cyanobacterial cluster are distantly related to the Archaea (Methanococcoides) and show a shallow branching from the Gram-positive bacteria (Bacillus subtilis) lineage. The cyanobacteria, as shown in other studies $(7,8)$, are not the most ancestral of bacterial groups even though this may be indicated by available microfossil evidence.

The relationships between cyanobacteria and photosynthetic organelles have also gained further confirmation by molecular systematics. Both the chloroplast of Euglena gracilis and the cyanelle of Cyanophora paradoxa form a distinct cluster closely related to the cyanobacteria. It appears that there was a common progenitor to both the photosynthetic organelle and cyanobacterial groups (9). It has been shown that green chloroplast $16 \mathrm{~S}$ rRNA sequences form a monophyletic lineage and that these origins are well placed within the cyanobacterial radiation $(8,10)$. Alternatively, oligonucleotide cataloguing revealed divergence of the chloroplast and cyanelle lineages prior to establishment of the diversity shown for extant specimens of cyanobacteria (11). In fact, a primary bifurcation of the derived 16S rRNA gene phylogeny (disregarding outgroups) shows a definite clustering of bacterial oxygenic phototrophs external to that of the organelles, whether they be more physiologically related to cyanobacteria or prochlorophytes. Woese (7) has also identified sequence signatures based on the $16 \mathrm{~S}$ rRNA primary structure which are shared by the cyanobacteria, Prochloron, and chloroplasts.

It appears that the prochlorales (Prochloron sp.) originated entirely from within the cyanobacterial radiation. Upon closer examination, a single ancestral taxon was the progenitor for filamentous, and heterocystous cyanobacteria (Nostoc PCC7120) and a cluster containing the prochlorophyte and Synechocystis lineages. Phylogenetic inferences by Wilmotte (10), based on $16 \mathrm{~S}$ rRNA sequences, confirm this clustering of Prochloron sp. with strains of Synechocystis. However, studies on the molecular diversity of this group of bacteria, which contain both chlorophyll $a$ and $b$, has revealed it to be polyphyletic with comparatively large genetic distances between representative strains (12-14).

Apart from 16S rRNA sequencing (8-10) few systems for classification, based on molecular genetics, have been proposed for cyanobacterial genera. This fact is particularly pertinent for those genera of toxin-producing cyanobacteria (15). Morphological differences between the proposed orders of cyanobacteria can be quite marked (2), although within these sections there are a number of specific taxonomic problems. These include the delineation of the genus Microcystis from Synechocystis, Anabaena from Nostoc, as well as Anabaena from the genera Aphanizomenon, Cylindrospermopsis, and Nodularia. In addition, the benthic and planktonic cyanobacteria of the 
Table 1. Primers for the amplification of the cyanobacterial 16S-23S rRNA ITS and phycocyanin operon

\begin{tabular}{|c|c|c|c|}
\hline Name & Sequence $^{a}$ & Locus & $\operatorname{Tm}\left({ }^{\circ} \mathrm{C}\right)^{\mathrm{b}}$ \\
\hline \multicolumn{4}{|l|}{ rRNA ITS } \\
\hline 23SRITS & TAGCAGGAAACAGCTATGAC-CCTCTGTGTGCCTAGGTATCC & $26-45$ (23S rRNA) & 58 \\
\hline 16SCITS & TGTAAAACGACGGCCAGTGAA-GTCGTAACAAGG & 1475-1505 (16S rRNA) & 94 \\
\hline \multicolumn{4}{|c|}{ Phycocyanin gene } \\
\hline $\mathrm{PC} \beta \mathrm{F}$ & GGCTGCTTGTTTACGCGACA & $c p c B$ gene & 57 \\
\hline PCaR & CCAGTACCACCAGCAACTAA & $c p c A$ gene & 55 \\
\hline
\end{tabular}

a Oligonucleotide sequences written in $5^{\prime}$ to $3^{\prime}$ orientation. Underlined sequences are those of the linked universal sequencing primers which were attached to assist in successive sequencing of PCR products.

${ }^{\mathrm{b}}$ Theoretical primer disassociation temperatures.

order Oscillatoriales present difficulties for accurate identification and classification. Amplification and restriction enzyme digestion or sequencing of PCR products has provided a specific method for the delineation of cyanobacterial genera (16-20). In particular, the genetic polymorphisms detected in the phycocyanin (PC) operon and the 16S-23S ribosomal RNA internal transcribed spacer (rRNA ITS) readily define genus boundaries and show varying degrees of concordance with traditional classification schemes. Molecular approaches to cyanobacterial identification are not influenced by ecological variables and in many instances do not require axenic or unicyanobacterial cultures for analysis. Indeed, due to the sensitivity afforded by DNA amplification technology, minute sample sizes, containing little cyanobacterial biomass, are required for the generation of genetic profiles.

Specific procedures involving DNA transfer and probe hybridisation have been previously employed, and allow the delineation of closely related and potentially toxic cyanobacteria $(3,21-24)$. However, most analyses of nucleic acids as molecular markers for cyanobacteria have focused on the relatively amorphous, unicellular genus
Synechococcus and the symbiotic filamentous genera Anabaena and Nostoc. These experiments were based on heterologous gene probe hybridisation to RFLPs of genomic DNA. RFLP data, corroborated by $16 \mathrm{~S}$ rRNA sequences $(8,11,25)$, show that diversity between marine and freshwater strains of Synechococcus, representing separate serogroups, was as great as that seen in the entire cyanobacterial radiation $(21,23,24,26)$. Similarly, RFLPs detected in the genomes of filamentous cyanobacteria revealed the presence of multiple lineages of symbiotic cyanobacteria associated with the Azolla fern (27), cycads (28) and angiosperms (29). These protocols, and hence their utility for cyanobacterial classification are limited by the complex experimental procedure, including a necessity for large quantities of DNA, and the lack of informative genotypes observed.

DNA amplification technology, combined with sequences of cyanobacterial genes, has provided an opportunity to design and develop rapid and sensitive protocols for detection and delineation of cyanobacterial strains. This article describes molecular methods which provide descriptive DNA profiles, composed of phylogenetic characters, which were appropriate for the inference of
A)

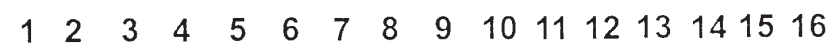

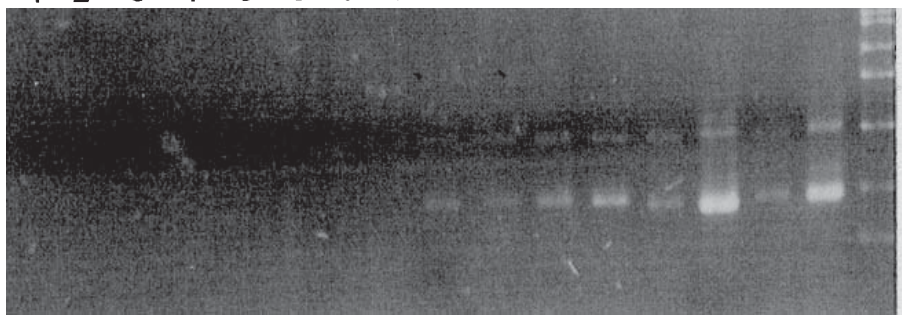

B)

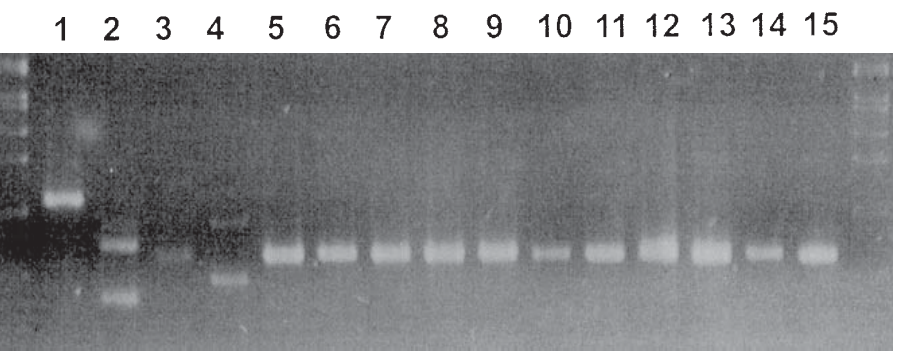

Figure 1. Specific amplification fragment length polymorphisms of the 16-23S ITS for the genera of cyanobacteria studied. Agarose gels ( $1 \%$ normal/ $1.5 \%$ low melt) were electrophoresed in TAE buffer and stained with ethidium bromide before photography using UV transillumination. A. Lanes 1 to 16 are the PCR products from Vibrio S14, Campylobacter jejuni, Helicobacter pylori, Proteus vulgaris, Klebsiella pneumonii, Lactobacillus fermentum, Rhizobium sp. NU259, Aeromonas sp. A234, A. circinalis NIES41, A. circinalis AWT001, A. circinalis AWT006, $A$. affinis NIES40, $A$. solitaria NIES80, $A$. flos aqua NIES73, A. spiroides NIES76, and Aphanizomenon flos aqua NIES81, respectively. Lane 17 is the molecular weight marker SPP-1/ECORI (marker bands of 720 and 480 bp approximately comigrate with the major and minor ITS bands of Anabaena). B. Lanes 1 and 17 are SPP-1/EcoRI. Lanes 2 to 16 correspond to PCR products from Pseudanabaena sp. (AWT), Cylindrospermopsis raciborskii AWT205, Nodularia PCC73104, Plectonema sp. (UNSW), Microcystis aeruginosa strains AWT139, PCC7806, PCC7820, PCC7941, PCC7005, NIES44, NIES298, NIES98, Microcystis wesenbergii strains NIES107, NIES111, and Microcystis viridis NIES102, respectively. Figure reproduced with permission (9). 
Table 2. Diagnostic RFLP types for cyanobacterial genera

\begin{tabular}{|c|c|c|c|c|c|c|c|c|c|}
\hline \multirow[t]{2}{*}{ Genus } & \multirow[b]{2}{*}{ Alul } & \multicolumn{8}{|c|}{ Restriction profile ${ }^{a}$ of amplified PC-IGS genes digested with: } \\
\hline & & Cfol & Haelll & HinFI & Mspl & Rsal & Taql & ScrFI & Sau3Al \\
\hline Anabaena & * & * & c & a & a & c & c & * & $\mathrm{b}$ \\
\hline Aphanizomenon & $\mathrm{b}$ & * & c & a & a & c & b & d & a \\
\hline Cylindrospermopsis & c & $\mathrm{h}$ & c & * & c & a & c & * & c \\
\hline Microcystis & * & * & * & c & b & a & a & * & * \\
\hline Nodularia & d & $\mathrm{h}$ & c & a & a & b & b & b & d \\
\hline Oscillatoria & c & c & * & * & b & c & a & * & b \\
\hline Pseudanabaena & $\mathrm{h}$ & c & c & d & a & c & c & b & b \\
\hline Synechococcus & c & e & a & c & d & a & a & b & a \\
\hline
\end{tabular}

a Multiple RFLP profiles designated by the asterisk ( $\left.{ }^{*}\right)$ exist for strains within these genera using the stated restriction endonuclease. The different patterns detected with each enzyme from 42 strains analysed are designated by lowercase letters (52).

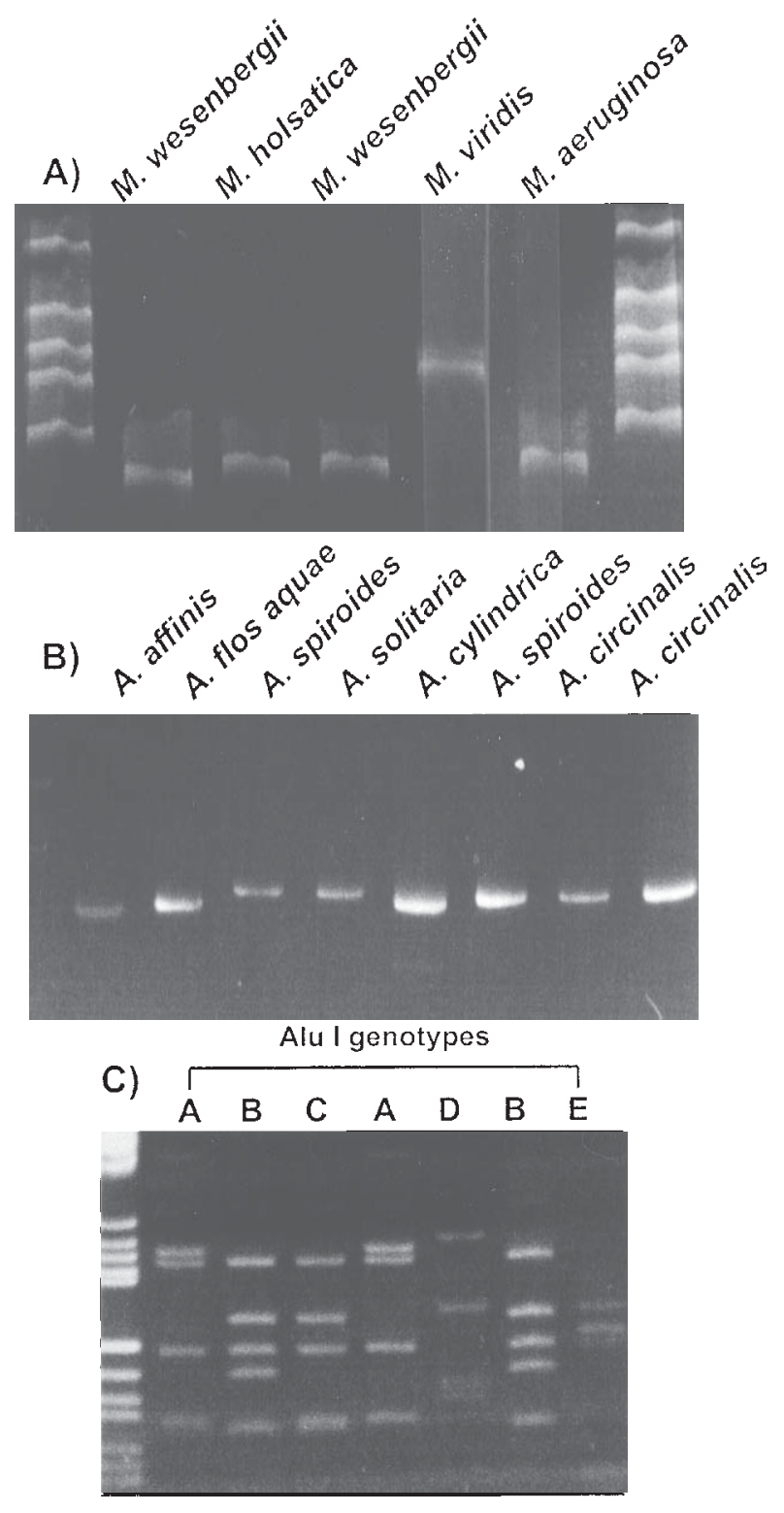

relatedness and evolution of cyanobacterial taxa. These phylogenetic characters provided differing levels of strain discrimination. The sensitivity of the methods described here are a reflection of the number of restriction endonuclease recognition sites in cyanobacterial- specific gene amplification products, in particular, the 16S-23S rRNA ITS and the phycocyanin operon. The DNA profiles generated depict genomic polymorphisms and allow the unambiguous identification of toxic cyanobacteria.

\section{Cyanobacterial Specific Gene Amplification and RFLP Analysis}

A cyanobacterial specific forward PCR primer was designed by targeting the 3 ' region of cyanobacterial $16 \mathrm{~S}$ rRNA gene sequences (Table 1). In combination with a bacterial consensus reverse 23S rRNA gene primer the selective amplification of the 16S-23S rRNA ITS from cyanobacteria within a consortium of other microorganisms was possible (9). Amplification of this region resulted in the detection of heterogeneity, with respect to the size of the PCR product, across several cyanobacterial genera. The genus Anabaena, for example, possessed two distinct PCR products, indicating the presence of multiple, heterologous rRNA operons. On the other hand, the genus Microcystis

Figure 2. Ethidium bromide stained gels showing the amplification products (undigested) for strains of cyanobacteria. A. Amplification products for strains of Microcystis electrophoresed on a 6\% polyacrylamide (19:1 crosslinked) gel in TBE buffer. M=molecular weight marker pBR322/Haelll. B. Amplification products (AFLPS) of the PC-IGS for strains of the genus Anabaena run on a $6 \%$ polyacrylamide gel (19:1 crosslinked) gel in TBE buffer. Molecular weight standard (M) is SPP1/EcoRI. C. Restriction digests of the PC-IGS PCR products of cyanobacteria electrophoresed on $6 \%$ polyacrylamide (19:1 crosslinked) gel in TBE buffer and stained with ethidium bromide. Illustration of the highly discriminatory restriction endonuclease Alul used in the present study. Five of the eight potential genotypes generated by this enzyme for the 40 strains studied are shown. Microcystis aeruginosa strains for the profiles shown are, from left to right; NIES111, AWT001, NIES112, NIES111, AWT104, AWT107, and AWT105. DNA molecular weight standard (M) is pUCBM21/Hpall-pUCBM21/Dral/ HindlII. Figure reproduced with permission (18). 


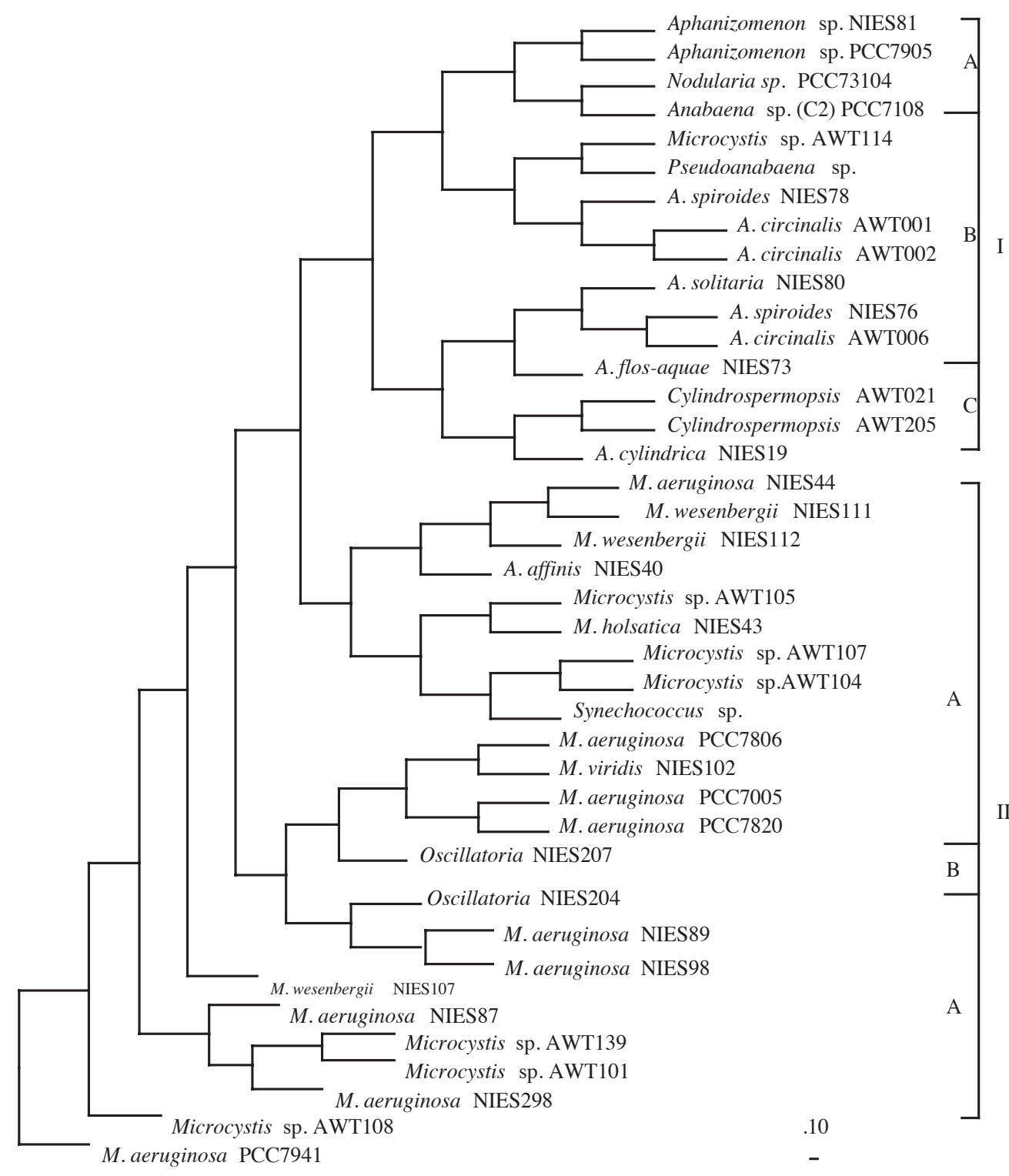

Figure 3. Strict consensus cladogram constructed from 45 binary characters applied to the rules of Dollo parsimony. The presence or absence of PC-IGS restriction digest patterns for each of the 40 strains was used as the basis for inferring cyanobacterial evolution. Twenty eight equally parsimonious trees were obtained using the DOLLOP program from the PHYLIP package and used to produce the presented tree. Relative genetic divergence is indicated by the scale. Figure reproduced with permission (18).

revealed a single amplification product for this region. Specific and discriminating amplification length fragments from the 16S-23S ITS were also observed for the genera Aphanizomenon, Cylindrospermopsis, Nodularia, Nostoc, Oscillatoria, Pseudanabaena, Plectonema, and Synechococcus (Figure 1).

In freshwater environments the phycocyanin operon is found almost exclusively in cyanobacteria. Amplification of the region spanning the intergenic spacer (IGS) between the two bilin subunit genes $c p c \mathrm{~B}$ and $c p c \mathrm{~A}$ allowed the rapid detection of small quantities of non-axenic cyanobacterial isolates (18). RFLP analysis of these amplification products, using up to 9 different four base pair recognition endonucleases, revealed an array of DNA profiles specific for toxin-producing cyanobacteria (Figure 2). Table 2 describes the restriction enzymes and genotypes which differentiate between certain cyanobacterial genera. Phylogenetic analysis of this data clustered the non-heterocystous, filamentous genera Oscillatoria with the unicellular genera Microcystis and Synechococcus as well as placing the strains $M$. elabens, $M$. holsatica, and numerous Australian isolates of Microcystis, on the same lineage as Synechococcus (Figure 3). All heterocyst-forming cyanobacteria studied appeared to share a common ancestor although species of Anabaena formed a polyphyletic lineage occupying 


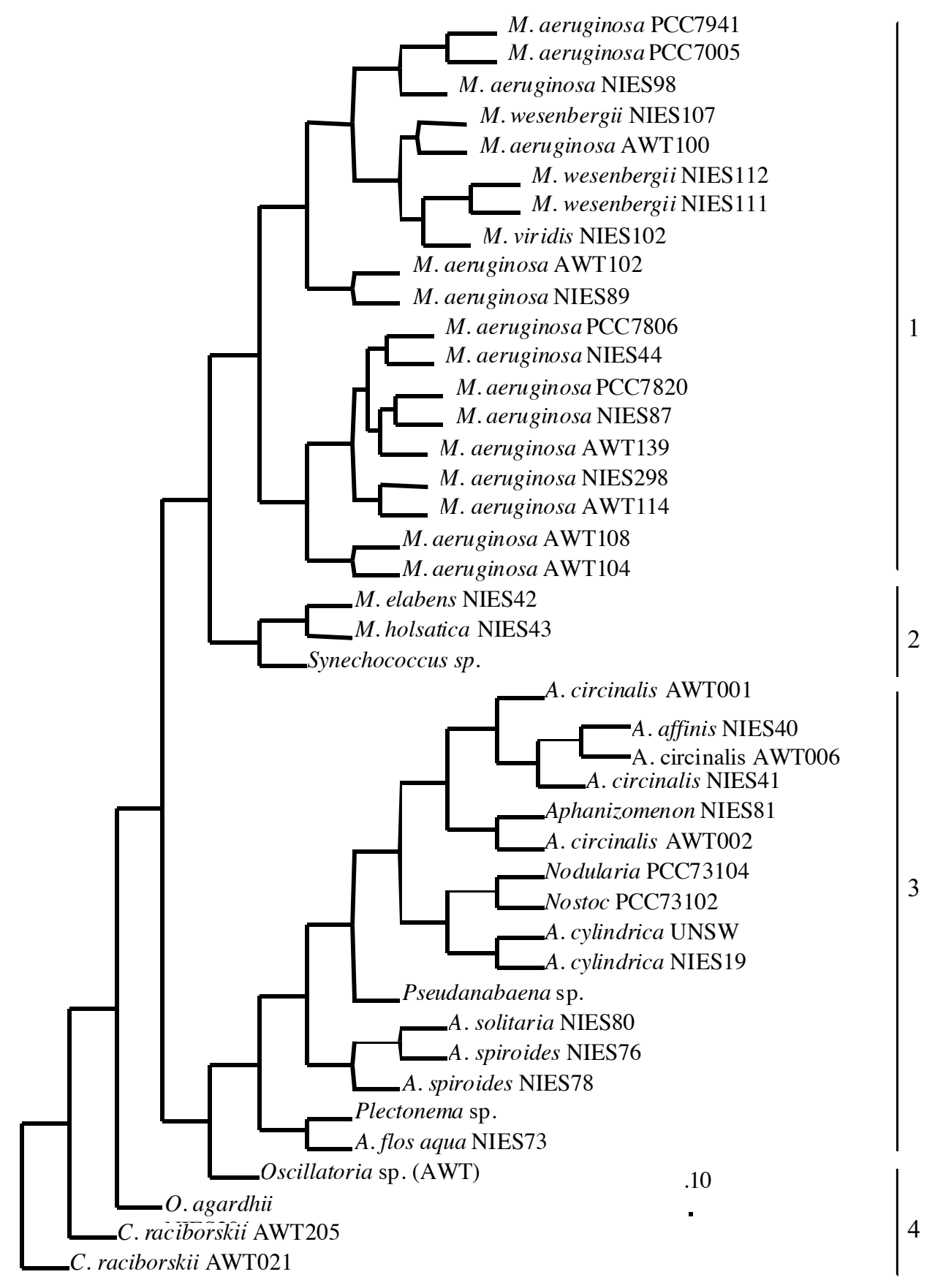

Figure 4. Relatedness of toxic and bloom-forming cyanobacteria based on RFLPs detected in the 16S-23S rRNA internal transcribed spacer region. The phylogeny was reconstructed using the Dollo parsimony program of the Phylip package. The strict consensus tree is shown with relative genetic distances for each branch indicated by the scale. Numbers 1 to 4 refer to the grouping of cyanobacterial clusters designated as Microcystis, Synechococcus, Anabaena, and Cylindrospermopsis/Oscillatoria, respectively. Figure reproduced with permission (9).

terminal branches with the genera Cylindrospermopsis, Aphanizomenon, and Nodularia. The genus Cylindrospermopsis, which has been recently isolated from Australia and produces hepatotoxic alkaloids (30), exhibited an early divergence from the rest of the heterocystous cyanobacteria. Interestingly, Nostoc strains in this study were not amplified using the described phycocyanin primer set, thus readily differentiating them from the Anabaena strains tested (18).

RFLPs of the amplified phycocyanin IGS and the 16S23S rRNA ITS revealed genotypes which were specific to the strain classification of cyanobacteria $(18,19)$. The diversity of genotypes detected by the 16S-23S rRNA ITS, however, was not as extensive as those revealed by the 
sequence polymorphisms in the cyanobacterial phycocyanin operon. Inferred phylogenies, using these RFLP genotypes as phylogenetic characters, are presented in Figures 3 and 4. Within the unicellular domains, Microcystis species generally occupied multiple lineages and exhibited no relation to their traditional taxonomic designations. Strains of $M$. aeruginosa from geographically distinct sources, however, did form a single cluster consistently across phylogenetic methods. Similarly, the presented trees did not delineate the Microcystis based on levels of hepatotoxin production. Based on mouse bioassay and protein phosphatase inhibition toxicity data there did not appear to be any correlation between the molecular evolution of phycocyanin genotypes and toxigenicity within the genus Microcystis. On the other hand, strains of Microcystis were clustered by 16S-23S rRNA ITS RFLPs with respect to their ability to produce microcystins, with all strains in the toxic cluster giving positive results for hepatotoxicity in the mouse bioassay (Figure 4). Bolch et al. (16) have investigated genetic polymorphisms within the phycocyanin operon and shown that considerably higher levels of intra-specific variation exists between strains of $M$. aeruginosa and Nodularia spumigena compared to strains of $A$. circinalis.

Both PCR-RFLP approaches showed strains of Oscillatoria to be monophyletic, although this was not supported by partial $16 \mathrm{~S}$ rRNA gene sequencing data, which depicted Oscillatoria to be a polyphyletic lineage with members closely related to different species of other filamentous and unicellular cyanobacteria (8). Strains of the genera Aphanizomenon and Nostoc were also shown to be monophyletic. Strains of Nostoc and Nodularia were also differentiated from the genus Anabaena by $16 \mathrm{~S}-23 \mathrm{~S}$ rRNA ITS genotyping, sharing a terminal branch with the A. cylindrica subgroup. Strains of $A$. circinalis, $A$. cylindrica, $A$. flos-aquae, $A$. solitaria, and $A$. spiroides were placed within the heterocystous cluster with no relation to their species designation (Figure 4). As with the strains of $M$. aeruginosa and $M$. wesenbergii, the strains of $A$. circinalis and $A$. spiroides were as different from each other as they are from supposedly more distantly related strains. The Cylindrospermopsis strains isolated from Australian waters were monophyletic and exhibited quite an early divergence from the rest of the heterocyst-forming cyanobacteria.

\section{Other DNA Amplification Procedures for Identification of Cyanobacteria}

The gross topology of the phylogenies inferred from polymorphisms in the phycocyanin and rRNA operons was also supported by RAPD profiles of toxic cyanobacteria. Multiplexing 10 mer oligonucleotides in a single PCR was used for generating reproducible and informative DNA profiles (31). Clustering of Anabaena and Microcystis by genomic heterogeneity as separate lineages reflected the obvious morphological differences as well as $16 \mathrm{~S}$ rRNA sequence divergence $(9,32)$. Other protocols involving nucleic acid content, including \%mol G+C (33) and DNA/ DNA hybridization (34), have successfully been applied to the classification of cyanobacteria, although non-axenic cultures and a continuum of genome content values and reassociation rates has made delineation of exact generic borders somewhat difficult.

Recently, the distribution of short tandem repeats in cyanobacterial genomes has been applied to the characterisation of toxic cyanobacteria. Rouhiainen et al. (3) has investigated many strains of toxin-producing cyanobacteria from several genera, including Anabaena and Microcystis, using the RFLPs detected by genomic transfer and hybridisation with a heptamer repeat of the nifJ gene. The results showed that readily distinguishable profiles were able to differentiate between filamentous, heterocystous cyanobacteria which were either neurotoxic (anatoxin-a) or hepatotoxic (microcystins). Cryptic short tandemly repeated sequences have also been described by Mazel et al. (22) and identified for use as molecular markers. However, caution should be adopted when applying these repeats to taxonomic studies, considering the potential mobility and amplification of such sequence elements. Cyanobacterial specific repeat sequences, termed highly iterative palindromes (HIP), have also revealed strain-specificity and can be applied to the discrimination of toxic and non-toxic cyanobacteria (3537). The use of RNA polymerase gene sequences has also been shown to discriminate between strains of Synechococcus-like cyanobacteria and prochlorophytes isolated from natural bacterioplankton communities (38).

Characterisation of the 16S rRNA gene has been applied to many prokaryote lineages and may reveal sequence signatures which are useful for the in situ detection of specific bacterial strains within their natural population structure $(39,40)$. Several other procedures are being developed for the cyanobacteria and other bacteria which allow discrimination of strains based on stable genetic characters. These include denaturing gradient gel electrophoresis and single stranded conformational polymorphisms (DGGE and SSCP), analysis of genomic restriction fragment polymorphisms by selective restriction fragment amplification (SRFA), and amplification of microsatellite (dinucleotide repeat) and repetitive extragenic repeat (REP) sequences (41). In addition, the phylogenetic affiliations amongst the toxin-producing and bloom-forming cyanobacteria are currently being investigated using inferences from recA (42) and 16S and 23S rRNA gene sequences (43, unpublished data).

\section{Different Levels of Taxonomic Discrimination}

The results of these studies show that genetic relatedness between the genera of bloom-forming cyanobacteria is supported by the described 16S-23S ITS and phycocyanin PCR-RFLP profiles. This system of molecular identification of cyanobacteria, when used in conjunction with traditional morphological evaluation, should continue to assist in the accurate delineation of novel isolates and the presentation of an amended system for cyanobacterial classification. The levels of sensitivity offered by molecular systematics are varied and afford a continuum of methods for strain discrimination. At the lowest taxonomic level, methods based on whole genome polymorphisms, such as RAPD PCR, readily differentiate between strains of cyanobacteria tested regardless of geographical origins $(16,31)$. The 
limitation of this technique is the current need for strains to be maintained in axenic and unicyanobacterial culture and has been shown not to be suitable for direct analysis of environmental isolates $(31,44)$. Decreased discriminatory power was afforded by the PCR-RFLP analyses of the ribosomal spacer and the phycocyanin operon, based on the methods in this article. These procedures were, however, more robust and useful for the direct analysis of cyanobacteria isolated from complex natural populations. Within this category it is recommended that the size of the 16S-23S rRNA ITS PCR product be used for initial confirmation of genus identification and successive restriction digest of this locus and that of the phycocyanin gene be applied for delineation to the strain level. However, sequencing of complete genes, such as the 16S rRNA gene, is becoming more efficient and provides the most accurate method for determining relatedness and inferring evolution within this group of prokaryotes. These amplification procedures are of particular value when combined with organism-specific primers, allowing direct "cyanodiversity" assessment from environmental samples.

Traditional taxonomic approaches to classification are no longer adequate given the available technology, and a polyphasic approach to systematics is more suitable and accurate for the description of members from natural microbial populations. The combination of phenotypic and genotypic characters provides both a means for classification and a tool for determining biological evolution.

\section{Protocols for DNA Extraction and Amplification}

Samples of type cultures and environmental isolates were harvested immediately upon receipt and PCR template prepared according to two methods. In Protocol 1, total genomic DNA was extracted using a modification of a method for purification of DNA from Gram-negative bacteria (31). As an alternative, the PCR template was prepared by the rapid lysis of cyanobacterial cells and liberation of DNA into the supernatant using Protocol 2.

\section{Primer Design and Amplification of the Phycocyanin IGS}

Oligonucleotide primers (Table 1) were designed to be suitable for amplification of the PC-IGS from a diverse range of cyanobacteria. Published peptide and DNA sequences for the PC operon, from the GenBank and EMBL databases, were aligned using the multiple sequence alignment program of the Clustal W package (45) supplied by the Australian National Genome Information Service (ANGIS, Sydney, Australia; morgan.angis.su.oz.au). The aligned PC sequences were from the cyanobacteria Anabaena sp. PCC7120, Calothrix sp. PCC7601, Pseudanabaena sp. PCC7409, Synechococcus sp. WH8020, Synechocystis sp. PCC6701, and Agmenellum quadruplicatum (Synechococcus) PCC7002 with GenBank accession numbers X05239, M36276, M99426, M95288, D13173, and K02660, respectively. PCR priming sites were chosen from completely conserved regions within the ( (forward primer) and ( (reverse primer) subunits of the PC peptide sequence. Codon bias for the photosynthetic apparatus genes of several cyanobacterial species was used to select the final DNA sequence of the PCR primers. The primer sequences were checked for homology to any other known sequences deposited in the available databases using the BLAST (46) option (ANGIS, Sydney, Australia). Peptide sequences in the regions chosen for these primers were also checked against those of red algae (Algaothamnion, Cyanidium, and Porphyridium), cryptomonads (Chroomonas) and cyanelle sequences in the PIR protein database. Oligonucleotides were synthesised using an Oligo 1000 DNA Synthesiser (Beckman, Fullerton, CA).

\section{Amplification Reactions}

Small volume (capillary) PCR was performed to study variability in the length of amplification products for the PCIGS. Reactions contained ( $20 \mu$ l reaction volume):

$67 \mathrm{mM}$ Tris- $\mathrm{HCl}, \mathrm{pH} 8.8$

$16 \mathrm{mM}\left(\mathrm{NH}_{4}\right)_{2} \mathrm{SO}_{4}$

$0.45 \%$ Triton $\mathrm{X}-100$

$200 \mathrm{mg} / \mathrm{ml}$ gelatin

$3 \mathrm{mM} \mathrm{MgCl}_{2}$

$200 \mu \mathrm{M}$ deoxynucleotide triphosphates

5 pmol of each oligonucleotide primer

0.5 units $T$ th Plus thermostable DNA polymerase (Biotech Int., Perth, Australia)

$1 \mu$ l of cell lysate supernatant or $50 \mathrm{ng}$ of genomic DNA

\section{Protocol 1. Genomic DNA isolation-1}

1. Pellet a $1 \mathrm{ml}$ aliquot of mid to late log phase culture by centrifugation, decant the media, and resuspend the pellet in $500 \mu$ l of $50 \mathrm{mM}$ Tris- $\mathrm{HCl}$ (pH 8.0), $5 \mathrm{mM}$ EDTA (pH 8.0), and $50 \mathrm{mM} \mathrm{NaCl}$.

2. Add lysozyme to give a final concentration of $1 \mathrm{mg} / \mathrm{ml}$ and incubate at $55^{\circ} \mathrm{C}$ for $30 \mathrm{~min}$.

3. Add $10 \mu \mathrm{l}$ proteinase $\mathrm{K}(10 \mathrm{mg} / \mathrm{ml})$ and $20 \mu \mathrm{l} 10 \% \mathrm{SDS}$ and incubate at $55^{\circ} \mathrm{C}$ for $10 \mathrm{~min}$ or until the solution clears (complete cell lysis).

4. Chill on ice and extract with an equal volume of phenol/chloroform/isoamylalcohol (25:24:1).

5. Repeat the organic extraction and add an equal volume of $4 \mathrm{M}$ ammonium carbonate to the supernatant.

6. Total genomic DNA is precipitated by addition of 2 volumes of isopropanol and centrifugation for $10 \mathrm{~min}$ at room temperature. 


\section{Protocol 2. Genomic DNA isolation-2}

1. Approximately $10^{5}$ to $10^{7}$ cells are centrifuged to a pellet and the culture medium removed.

2. The cells are resuspended in $200 \mu$ l of Instagene matrix (Bio-Rad, Hercules, CA.) supplemented with $20 \mu$ of $1 \%$ NP-40 or $1 \%$ Triton X-100.

3. Cells are incubated at $55^{\circ} \mathrm{C}$ for $30 \mathrm{~min}$, vortexed for one minute and heated to $95^{\circ} \mathrm{C}$ for 10 min.

4. The solution is vortexed again for one mine and the cell debris pelleted by a brief centrifugation.

5. Between 1 and $5 \mu \mathrm{l}$ of the supernatant contained sufficient genetic material for a successful PCR amplification. Supernatant of this cell lysate has been stored at $4^{\circ} \mathrm{C}$ for over 2 years and found to retain sufficient DNA for a PCR template.

Reactions were carried out in heat sealed positive displacement pipette tips. Initial denaturation of template DNA was achieved by incubation at $94^{\circ} \mathrm{C}$ for $2 \mathrm{~min}$. Reactions were then subjected to 40 cycles of $94^{\circ} \mathrm{C}, 5$ sec; $47^{\circ} \mathrm{C}, 10 \mathrm{sec}$; and $72^{\circ} \mathrm{C}, 30 \mathrm{sec}$ in an FTS-1S capillary thermocycler (Corbett Research, Sydney, Australia). Largescale DNA amplifications were required for successive restriction fragment analysis of the PCR product. They contained $2.5 \mathrm{mM} \mathrm{MgCl}_{2}, 20$ pmol of each primer, 2 units Tth Plus thermostable DNA polymerase (Biotech Int., Perth, Australia), and $2 \mu \mathrm{l}$ of cell lysate or $100 \mathrm{ng}$ of genomic DNA in a $100 \mu$ l volume. All other components were at the same concentration as $20 \mu \mathrm{l}$ reactions. Reactions were overlayed with mineral oil and incubated at $94^{\circ} \mathrm{C}$ for $5 \mathrm{~min}$ to denature the PCR template. The reaction tube was immediately subjected to 40 cycles of $20 \mathrm{sec}$ at $94^{\circ} \mathrm{C}, 30$ sec at $50^{\circ} \mathrm{C}$, and $60 \mathrm{sec}$ at $72^{\circ} \mathrm{C}$. PCR products were analysed by electrophoresis in $1 \%$ agarose in TAE buffer.

\section{Primer Design and Amplification of the 16S-23S rDNA ITS}

Oligonucleotide primers (Table 1) were designed to be suitable for amplification of the ITS from a diverse range of cyanobacteria. Published DNA sequences for the $16 \mathrm{~S}$ rRNA genes from cyanobacteria were aligned using the multiple sequence alignment program of the Pileup and Clustal W packages (45). The aligned 16S rRNA gene sequences were from the cyanobacteria Anabaena sp. PCC7120, Synechococcus sp. PCC6301, Chlorogloeopsis HTF PCC7518, Microcystis aeruginosa PCC7806, and Microcystis aeruginosa NIES89 with GenBank accession numbers X59559, X01296, X68780, Z28699, and Z28700, respectively. Potential cyanobacterial specific PCR priming sites were chosen from within the conserved sequences of the $3^{\prime}$ region of these $16 \mathrm{~S}$ rRNA molecules. Conserved sequences at the 5 ' region of bacterial $23 \mathrm{~S}$ rRNA genes were used as the target for a downstream, reverse PCR primer (19). The forward primer (16CITS) sequence was checked for identity to $16 \mathrm{~S}$ rDNA sequences or homology to any other sequences using the BLAST (46) search algorithm against sequences contained in the ribosomal database project and the GenBank and EMBL nucleotide sequence databases.

Large-scale DNA amplifications were performed as for the phycocyanin operon PCR except that the reaction tube was subjected to 30 cycles of $20 \mathrm{sec}$ at $94^{\circ} \mathrm{C}, 30 \mathrm{sec}$ at $48^{\circ} \mathrm{C}$, and $60 \mathrm{sec}$ at $72^{\circ} \mathrm{C}$ in a PE480 thermal cycler (PerkinElmer Cetus, Emeryville, CA). The cyanobacterial specific ITS PCR also required a hot-start protocol which entailed the addition of thermostable DNA polymerase to other PCR components which had been preheated to $96^{\circ} \mathrm{C}$. PCR cycling was commenced directly after addition of the enzyme.

\section{Restriction Endonuclease Digestion of 16S-23S rRNA ITS and PC-IGS PCR Products}

PCR fragments were purified from reaction components and small by-products as described by Neilan et al. (18). Mineral oil was removed from $\mathrm{PCR}$ reactions by chloroform: isoamyl alcohol (23: 1) extraction. The aqueous phase was then purified using the Wizard PCR purification system (Promega, Madison, WI) to remove amplification reaction components including unincorporated primers and nucleotides. ITS amplification fragments were digested separately with eight restriction endonucleases which recognise and cleave tetra-nucleotide motifs. The DNA restriction enzymes Alul, Cfol, Haelll, HinFI, Mspl, Rsal, ScrFl, and Taql (Boehringer Mannheim, Germany) were used to generate RFLP patterns specific to the cyanobacterial strains studied as previously described (18). Approximately $200 \mathrm{ng}$ of PCR product was combined with $1.5 \mu \mathrm{l}$ of the corresponding enzyme buffer supplied and 5 units of restriction enzyme in a $15 \mu$ ldigest. Reactions were incubated overnight at the temperature recommended by the enzyme supplier. All PCR products were analysed by electrophoresis in $1 \%$ normal agarose / $1.5 \%$ low melt agarose in TAE buffer or $6 \%$ polyacrylamide (19: 1, acrylamide: bisacrylamide) in TBE buffer. DNA in agarose gels was stained with ethidium bromide or with silver nitrate when electrophoresed in an acrylamide matrix (47). The profile of a each digest was used as a genotypic marker and formed the basis for phylogenetic analyses.

\section{Phylogenetic Analysis of RFLP Data}

The RFLP patterns generated were based on the primary structure of the rRNA ITS and the PC operon. These DNA profiles were treated as observed phenotypes for the purpose of inferring relatedness between the 
cyanobacteria. Phylogenetic analysis of the data was performed by calculating pairwise genetic distances from a binary matrix. Each strain or operational taxonomic unit (OTU) was identified by the presence or absence of a RFLP profile for each of the nine restriction digests. Distance calculations were performed using the eighteen algorithms supplied by the RAPDistance package developed by Armstrong et al. (48). All metrics available were used and the resulting trees constructed by the neighbour-joining method and the NJTREE program (49). The RFLP profiles were also used in a cladistic analysis where character changes were minimised along branches of the derived tree. The rules of parsimony, using the Dollo parsimony method supplied by the DOLLOP program in the PHYLIP package (version 3.53c), were applied to the profile data $(50,51)$. Relatedness between strains was inferred based on the number of shared homologous characters, being RFLP profiles for this study. A single, strict consensus cladogram was reconstructed, using the majority-rule method, from the equally parsimonious trees found. Outgroups were not available for this study and therefore the phylogenetic trees presented should be considered as unrooted.

\section{Concluding Remarks}

The application of nucleic-acid based and, more importantly, DNA amplification methods for the molecular typing of microorganisms in complex natural populations is making the study of cyanobacterial systematics and phylogenetics definitive rather than descriptive. The speed, economy, sensitivity, and reliability of the PCR-based methods described in this study make them ideal for accurately addressing basic questions in microbial ecology. The present work has provided DNA profiles, composed of phylogenetic characters, appropriate for the inference of relatedness and evolution of cyanobacterial taxa. These DNA profiles readily identify potential toxic species of bloom-forming or benthic cyanobacteria in drinking and recreational water supplies. In addition, most of these molecular taxonomic methods are, or will soon be, amenable to automation. For both environmentally and medically significant microbial populations this technology provides high-level discrimination for the detection of toxic or virulent strains. Apart from pathogenicity, the unambiguous identification of microorganisms is also crucial to other fields including, bioremediation, biotechnology, and biodiversity.

\section{References}

1. Baker, P. D. 1992. Identification of common toxic noxious cynaobacteria, Part II-Chroococcales, Oscillatoriales. Urban Water Research Association of Australia, Melbourne.

2. Rippka, R. 1988. Recognition and identification of cyanobacteria. Methods Enzymol. 167: 28-67.

3. Rouhiainen L., K. Sivonen, W. J. Buikema, and R. Haselkorn. 1995. Characterisation of toxin-producing cyanobacteria by using an oligonucleotide probe containing a tandemly repeated heptamer. J. Bacteriol.
177: 6021-6026.

4. Gibbons, N. E., and R. G. E. Murray. 1978. Proposals concerning the higher taxa of bacteria. Int. J. Syst. Bacteriol. 28: 1-6.

5. Stanier, R. Y., W. R. Sistrom, T. A. Hansen, B. A. Whitton, R. W. Castenholz, N. Pfenning, V. N. Gorlenko, E. N. Kondratieva, K. E. Eimhjellen, R. Whittenbury, R. L. Gherna, and H. G. Truper. 1978. Proposal to place the nomenclature of the cyanobacteria (blue-green algae) under the rules of the International Code of Nomenclature of Bacteria. Int. J. Syst. Bacteriol. 28: 335-336.

6. Doolittle, W. F. 1982. Molecular evolution. In: The Biology of Cyanobacteria, Volume 19. N. G. Carr and B. A. Whitton, eds. Berkeley, University of California Press. p. 307-332.

7. Woese, C. R. 1987. Bacterial evolution. Microbiol. Rev. 51: 221-271.

8. Giovannoni, S. J., S. Turner, G. J. Olsen, S. Barns, D. J. Lane, and N. R. Pace. 1988. Evolutionary relationships among cyanobacteria and green chloroplasts. J. Bacteriol. 170: 3584-3592.

9. Neilan B. A., J. Stuart, P. R. Hawkins, P. T. Cox, and A. E. Goodman. 1997a. Molecular characterisation of cyanobacterial populations by specific amplification and restriction endonuclease digestion of the ribosomal RNA gene internal transcribed spacer. Syst. Appl. Microbiol. 20: 612-621.

10. Wilmotte, A. 1994. Molecular evolution and taxonomy of the cyanobacteria. In: The Molecular Biology of Cyanobacteria. D. A. Bryant, ed. Kluwer Academic Publishers, Netherlands. p. 1-25.

11. Bonen, L., and W. F. Doolittle. 1978. Ribosomal RNA homologies and the evolution of the filamentous bluegreen bacteria. J. Mol. Evol. 10: 283-291.

12. Palenik, B., and R. Haselkorn. 1992. Multiple evolutionary origins of prochlorophytes, the chlorophyll b-containing prokaryotes. Nature. 335: 265-267.

13. Turner, S., T. Burger-Wiersma, S. J. Giovanonni, L. R. Mur, and N. R. Pace. 1989. The relationships of a prochlorophyte, Prochlorothrix hollandica, to green chloroplasts. Nature. 337: 380-382.

14. Urbach, E., D. L. Robertson, and S. W. Chisholm. 1992. Multiple evolutionary origins of prochlorophytes within the cyanobacterial radiation. Nature. 335: 267-269.

15. Carmichael, W. W. 1994. The toxins of cyanobacteria. Sci. Am. 270: 78-86.

16. Bolch C. J. S., S. I. Blackburn, B. A. Neilan, and P. M. Grewe. 1996. Genetic characterization of strains of cyanobacteria using PCR-RFLP of the $c p c B A$ intergenic spacer and flanking regions. J. Phycol. 32: 445-451.

17. Lu, W. Q., Evans, E. H., Mccoll, S. M. and V. A. Saunders. 1997. Identification of cyanobacteria by polymorphisms of PCR-amplified ribosomal DNA spacer region. FEMS Microbiol. Lett. 153: 141-149.

18. Neilan, B. A., D. Jacobs, and A. E. Goodman. 1995. Genetic diversity and phylogeny of toxic cyanobacteria determined by DNA polymorphisms within the phycocyanin locus. Appl. Environ. Microbiol. 61: 38753883. 
19. Neilan B. A., D. Jacobs, T. Del Dot, L. Blackall, P. R. Hawkins, P. T. Cox, and A. E. Goodman. 1997. Ribosomal RNA sequences and evolutionary relationships among the toxigenic cyanobacteria of genus Microcystis. Int. J. Syst. Bacteriol. 47: 693-697.

20. Otsuka, S., Suda, S., Li, R. H., Watanabe, M., Oyaizu, H., S. Matsumoto S., and M. M. Watanabe. 1999. Phylogenetic relationships between toxic and non-toxic strains of the genus Microcystis based on 16S to $23 S$ internal transcribed spacer sequence. FEMS Microbiol. Lett. 172: 15-21.

21. Douglas, S. E., and N. G. Carr. 1988. Examination of genetic relatedness of marine Synechococcus spp. by using restriction fragment length polymorphisms. Appl. Environ. Microbiol. 54: 3071.

22. Mazel D., J. Houmard, A. M. Castetes, and N. Tandeau de Marsac. 1990. Highly repetitive DNA sequences in cyanobacterial genomes. J. Bacteriol. 172: 2755-2761.

23. Wood, A. M., and S. Golden. 1988. Restriction fragment length polymorphisms among strains of marine Synechococcus. J. Phycol. 24: 25.

24. Wood, A. M., and D. Townsend. 1990. DNA polymorphisms within the WH7803 serogroup of marine Synechococcus spp. (cyanobacteria). J. Phycol. 26: 576-585.

25. Honda, D., Yokota, A. and J. Sugiyama. Detection of seven major evolutionary lineages in cyanobacteria based on the 16S rRNA gene sequence analysis with new sequences of five marine Synechococcus strains. J. Mol. Evol. 48: 723-739.

26. Adams, D. G. 1988. Isolation and restriction analysis of DNA from heterocysts and vegetative cells of cyanobacteria. J. Gen. Microbiol. 134: 2943-2949.

27. Gebhardt, J. S., and S. A. Nierzwicki-Bauer. 1991. Identification of a common cyanobacterial symbiont associated with Azolla spp. through molecular and morphological characterisation of free-living and symbiotic cyanobacteria. Appl. Environ. Microbiol. 57: 2141-2146.

28. Lindblad, P., R. Haselkorn, B. Bergman, and S. A. Nierwicki-Bauer. 1989. Comparison of DNA restriction fragment length polymorphisms of Nostoc strains in and from cycads. Arch. Microbiol. 152: 20-24.

29. Zimmerman, W. J., and B. Bergman. 1990. The Gunnera symbiosis: DNA restriction fragment length polymorphism and protein comparisons of Nostoc symbionts. Microb. Ecol. 19: 291-302.

30. Hawkins P. R., M. T. C. Runnegar, A. R. B. Jackson, and I. R. Falconer. 1985. Severe hepatotoxicity caused by the tropical cyanobacterium (blue-green alga) Cylindrospermopsis raciborskii (Woloszynska) Seenaya and Subba Raju isolated from a domestic water supply reservoir. Appl. Environ. Microbiol. 50: 1292-1295.

31. Neilan, B. A. 1995. Identification and phylogenetic analysis of toxigenic cyanobacteria using a multiplex RAPD PCR. Appl. Environ. Microbiol. 61: 2286-2291.

32. Neilan, B. A., P. T. Cox, P. R. Hawkins, and A. E. Goodman. 1994. 16S ribosomal RNA gene sequence and phylogeny of toxic Microcystis sp. (cyanobacteria). DNA Sequence 4: 333-337.
33. Herdman, M., M. Janvier, J. B. Waterbury, R. Rippka, and R.Y. Stanier. 1979. DNA base composition of cyanobacteria. J. Gen. Microbiol. 111: 63-71.

34. Lachance, M. A. 1981. Genetic relatedness of heterocystous cyanobacteria by deoxyribonucleic aciddeoxyribonucleic acid reassociation. Int. J. Syst. Bacteriol. 31: 139.

35. Robinson, N. J., Robinson, P. J., Gupta, A., Bleasby, A. J., Whitton, B. A. and A. P. Morby. 1995. Singular over-representation of an octameric palindrome, HIP1, in DNA from many cyanobacteria. Nucleic Acids Res. 23: 729-735.

36. Saker, M. and B. A. Neilan. 2001. Varied diazofrophies, morphologies, and toxicities of genetically similar isolates of Cylindrospermopsis raciborskii (Nostocales, Cyanophyceae) from Northern Australis. Appl. Environm. Microbiol. 67: 1839-1845.

37. Smith, J. K., Parry, J. D., Day, J. G. and Smith R. J. (1998) A PCR technique based on the Hip1 interspersed repetitive sequence distinguishes cyanobacterial species and strains. Microbiol. 144: 2791-2801.

38. Palenik, B. 1994. Cyanobacteria community structure as seen from RNA polymerase gene sequence analysis. Appl. Environ. Microbiol. 60: 3212-3219.

39. Amann, R. I., B. J. Binder, R. J. Olson, S. W. Chisolm, R. Devereux, and D. A. Stahl. 1990. Combination of 16S rRNA-targeted oligonucleotide probes with flow cytometry for analysing mixed microbial populations. Appl. Environ. Microbiol. 56: 1919-1925.

40. Jacobs, D., M. Angles, A. E. Goodman, and B. A. Neilan. 1996. In situ enzymatic amplification and detection of low copy number genes in bacteria. FEMS. Microbiol. Lett. 152: 65-73.

41. Neilan, B. A. 1998. DNA profiling of complex bacterial populations: toxic cyanobacterial blooms. Rec. Res. Adv. Microbiol. 1: 277-296.

42. Adams, D. H. 1995. Cloning, sequencing, and phylogenetic studies of the recA gene of Microcystis aeruginosa PCC7005. Honours Thesis, Flinders University of South Australia. p. 105.

43. Douglas, S. E., and W. F. Doolittle. 1984. Complete nucleotide sequence of the 23S rRNA gene of the cyanobacterium, Anacystis nidulans. Nucleic Acids Res. 12: 3373-3386.

44. Van Coppenhole, B., I. Watanabe, C. Van Hove, G. Second, N. Huang, and S. R. McCouch. 1993. Genetic diversity and phylogeny analysis of Azolla based on DNA amplification by arbitrary primers. Genome. 36: 686-693.

45. Thompson, J. D., D. G. Higgins, D.G., and T. J. Gibson. 1994. CLUSTAL W: Improving the sensitivity of progressive multiple sequence alignment through sequence weighting, position specific gap penalties and weight matrix choice. Nucleic Acids Res. 22: 46734680 .

46. Altschul, S. F., W. Gish, W. Miller, E. W. Myers, and D. J. Lipman. 1990. Basic local alignment search tool. J. Mol. Biol. 215: 403-410.

47. Neilan, B. A., D. A. Leigh, E. Rapley, and B. L. 
McDonald. 1994b. Microsatellite genome screening: rapid non-denaturing, non-isotopic dinucleotide repeat analysis. BioTechniques. 17: 708-712.

48. Armstrong, J., A. Gibbs, R. Peakall, and G. Weiller. 1994. The RAPDistance Package. ftp: //life.anu.edu.au (150.203.38.74) pub/molecular_biology/rapdpack.exe

49. Saitou, N. and Nei, M. 1987. The neighbor-joining method: a new method for reconstructing phylogenetic trees. Mol. Biol. Evol. 4: 406-425.

50. Felsenstein, J. 1983. Parsimony in systematics: biological and statistical issues. Ann. Rev. Ecol. Syst. 14: 313.

51. Felsenstein, J. 1989. PHYLIP. Phylogeny inference package. Cladistics 5: 164-166.

52. Neilan, B. A. 1996. Detection and identification of cyanobacteria associated with toxic blooms: DNA amplification protocols. Phycologia. 35: 147-155. 


\section{Further Reading}

Caister Academic Press is a leading academic publisher of advanced texts in microbiology, molecular biology and medical research. Full details of all our publications at caister.com

- MALDI-TOF Mass Spectrometry in Microbiology Edited by: M Kostrzewa, S Schubert (2016) www.caister.com/malditof

- Aspergillus and Penicillium in the Post-genomic Era Edited by: RP Vries, IB Gelber, MR Andersen (2016) www.caister.com/aspergillus2

- The Bacteriocins: Current Knowledge and Future Prospects Edited by: RL Dorit, SM Roy, MA Riley (2016)

www.caister.com/bacteriocins

- Omics in Plant Disease Resistance Edited by: V Bhadauria (2016) www.caister.com/opd

- Acidophiles: Life in Extremely Acidic Environments Edited by: R Quatrini, DB Johnson (2016) www.caister.com/acidophiles

- Climate Change and Microbial Ecology: Current Research and Future Trend

Edited by: J Marxsen (2016)

www.caister.com/climate

- Biofilms in Bioremediation: Current Research and Emerging Technologies

Edited by: G Lear (2016)

www.caister.com/biorem

- Microalgae: Current Research and Applications Edited by: MN Tsaloglou (2016) www.caister.com/microalgae

- Gas Plasma Sterilization in Microbiology: Theory, Applications, Pitfalls and New Perspectives Edited by: H Shintani, A Sakudo (2016) www.caister.com/gasplasma

- Virus Evolution: Current Research and Future Directions Edited by: SC Weaver, M Denison, M Roossinck, et al. (2016) www.caister.com/virusevol

- Arboviruses: Molecular Biology, Evolution and Control Edited by: N Vasilakis, DJ Gubler (2016) www.caister.com/arbo

- Shigella: Molecular and Cellular Biology Edited by: WD Picking, WL Picking (2016) www.caister.com/shigella

-Aquatic Biofilms: Ecology, Water Quality and Wastewater Treatment

Edited by: AM Romaní, H Guasch, MD Balaguer (2016)

www.caister.com/aquaticbiofilms

- Alphaviruses: Current Biology

Edited by: S Mahalingam, L Herrero, B Herring (2016)

www.caister.com/alpha

- Thermophilic Microorganisms

Edited by: F Li (2015)

www.caister.com/thermophile
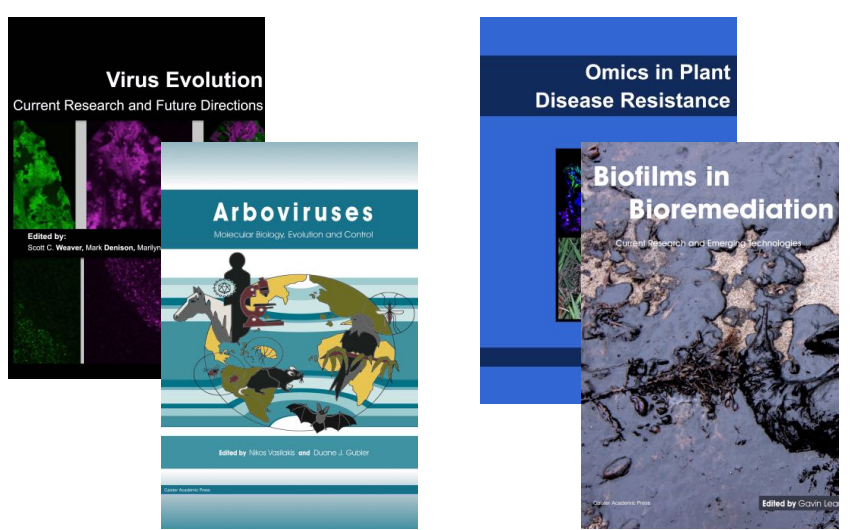
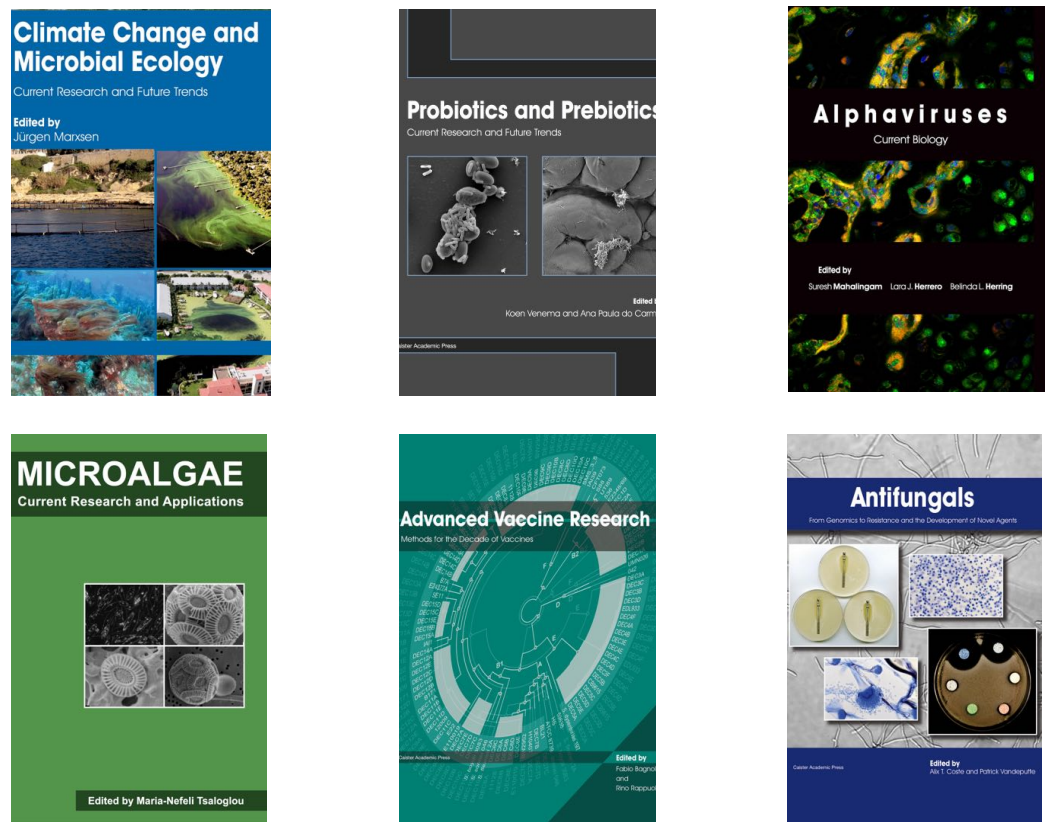

- Flow Cytometry in Microbiology: Technology and Applications Edited by: MG Wilkinson (2015) www.caister.com/flow

- Probiotics and Prebiotics: Current Research and Future Trends Edited by: K Venema, AP Carmo (2015) www.caister.com/probiotics

- Epigenetics: Current Research and Emerging Trends Edited by: BP Chadwick (2015) www.caister.com/epigenetics2015

- Corynebacterium glutamicum: From Systems Biology to Biotechnological Applications

Edited by: A Burkovski (2015)

www.caister.com/cory2

- Advanced Vaccine Research Methods for the Decade of Vaccines

Edited by: F Bagnoli, R Rappuoli (2015)

www.caister.com/vaccines

- Antifungals: From Genomics to Resistance and the Development of Novel Agents

Edited by: AT Coste, P Vandeputte (2015)

www.caister.com/antifungals

- Bacteria-Plant Interactions: Advanced Research and Future Trends Edited by: J Murillo, BA Vinatzer, RW Jackson, et al. (2015) www.caister.com/bacteria-plant

\section{- Aeromonas}

Edited by: J Graf (2015)

www.caister.com/aeromonas

- Antibiotics: Current Innovations and Future Trends

Edited by: S Sánchez, AL Demain (2015)

www.caister.com/antibiotics

- Leishmania: Current Biology and Contro Edited by: S Adak, R Datta (2015) www.caister.com/leish2

- Acanthamoeba: Biology and Pathogenesis (2nd edition) Author: NA Khan (2015)

www.caister.com/acanthamoeba2

- Microarrays: Current Technology, Innovations and Applications Edited by: Z He (2014)

www.caister.com/microarrays2

- Metagenomics of the Microbial Nitrogen Cycle: Theory, Methods and Applications

Edited by: D Marco (2014)

www.caister.com/n2 